\title{
Synthesis of Nano-Fluorohydroxyapatite Thin Films by Sol-Gel Method
}

\section{Majid Darroudi ${ }^{1}{ }^{*}$, Hossein Eshtiagh-Hosseini ${ }^{1}$, Mohammad Reza Housaindokht ${ }^{1}$ \& Abbas Youssefi $^{2}$}

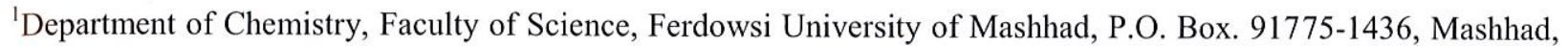
Iran

${ }^{2}$ Mashhad Glaze Company, Par-e-Tavous Research Institute, Road of Ghouchan, Mashhad, Iran

*majiddarroudi@gmail.com (Corresponding author)

Received in $15^{\text {th }}$ September 2010, accepted in revised form $15^{\text {th }}$ November 2010.

ABSTRACT It is realized that the surface of biomedical metallic implants covered by fluorohydroxyapatite, $\left[\mathrm{Ca}_{10}\left(\mathrm{PO}_{4}\right)_{6}(\mathrm{OH}, \mathrm{F})\right]$ (FHA) can create bioactivity of the implant and shorten healing time. In this work FHA, in the form of powders and of thin films on titanium substrates, were synthesized by sol-gel spin coating method, using calcium nitrate tetrahydrate $\left(\mathrm{Ca}\left(\mathrm{NO}_{3}\right)_{2}\right) \cdot 4 \mathrm{H}_{2} \mathrm{O}$, phosphorous pentoxide $\left(\mathrm{P}_{2} \mathrm{O}_{5}\right)$ and ammonium fluoride $\left(\mathrm{NH}_{4} \mathrm{~F}\right)$ to provide Ca-precursor, P-precursor and fluorine reagent, respectively. The FHA powders were calcined and thin films were fired at temperatures ranging from $500-800^{\circ} \mathrm{C}$. The constituent of both powders and thin films were confirmed as FHA using X-ray diffraction (XRD) and Fourier transform Infrared spectroscopy (FTIR). The thermal stability of FHA powders was studied by differential thermal analysis (DTA). The optimized calcination and firing temperature was $600{ }^{\circ} \mathrm{C}$. Transmission electron microscopy (TEM) results with Debye-Scherrer equation gave the size of the FHA particles in nano-scale range. The films were found to be quite uniform and dense by SEM.

(Keywords: Sol-gel, fluorohydroxyapatite, thin films, spin coating)

\section{INTRODUCTION}

The clinical applications of calcium phosphates constitute an interesting field of research and development in the production of useful biomaterials for implant fabrication and/or fixation. Biomaterials in general and bioceramics in particular allow replacement of several parts of our body $[1,2]$. The most used calcium phosphate in implant fabrication is hydroxyapatite $\left[\mathrm{HA}, \mathrm{Ca}_{10}\left(\mathrm{PO}_{4}\right)_{6}(\mathrm{OH})_{2}\right]$, since it has similar characteristics as the mineral component of bones. It exhibits good properties as biomaterial, such as biocompatibility, bioactivity, osteoconductivity and direct bonding to bone [3].

HA, which has the similar chemical composition and the crystal structure to apatite in the human skeletal system, has attracted much interest as an implant material in clinical applications [4]. Bone tissue can rapidly grow along the surface of the HA implant in the presence of a rich calcium and phosphorous environment, forming firm chemical bonds between $\mathrm{HA}$ and bone tissues without any intervening soft tissue layer $[5,6]$. Despite its excellent biocompatibility and efficacious biological fixation to bony tissues, HA has poor mechanical properties in bulk form such as ductility and toughness, and this has restricted its use in load bearing applications [7]. HA is now often coated on a metal substrate such as Titanium (Ti) and its alloys constituting a new implant which combines the superior mechanical performance of the metal component with the excellent biological responses of the HA ceramic $[8,9]$. Metallic biomaterials, such as Ti and its alloys, have enjoyed clinical success because of their superior strength, biocompatibility, durability, and resistance to corrosion in physiological environment [10]. The high mechanical strength and toughness of these bio-metals are the most important advantages over bioactive ceramics, which are inherently weak and brittle [11].

$\mathrm{Ti}$ and its alloys have long been used as implant materials in dental and orthopedic applications [12]. To improve the implant-tissue osseointegration, much effort has gone into the modification of the Tisurface [13-15]. Among the various attempts, made to improve osseointegration, $\mathrm{HA}$ coatings on $\mathrm{Ti}$ implants have shown not only good fixation to the host bone and but also increased bone ingrowths to the implant [16]. The improved biocompatibility provided by the HA coatings is due its chemical and biological similarity to hard tissues, and its consequent direct bonding to host bones [17]. The bone in growth properties and implant fixation behavior need to be improved in order to shorten the implant-tissue osseointegration time [18]. However, pure HA suffers relatively high dissolution rate in simulated body fluid, which affects its long-term stability. High dissolution may lead to disintegration 
of the coatings and hinder the fixation of implant to the host tissue $[19,20]$. Fluorine ion, which exists in human bone and enamel, can be incorporated into HA crystal structure by substitution of $\mathrm{F}^{-}$ions for $\mathrm{OH}$ groups to form fluorohydroxyapatite (FHA, $\mathrm{Ca}_{10}\left(\mathrm{PO}_{4}\right)_{6}(\mathrm{OH})_{2-\mathrm{x}} \mathrm{F}_{\mathrm{x}}$, where $0<\mathrm{x}<2$ is the degree of fluoridation, and $x=0$, pure $\mathrm{HA} ; \mathrm{x}=2$, pure $\mathrm{FA}$ ). Incorporation of fluorine into HA, or "fluoridation", reduces the solubility, and maintains a comparable biocompatibility to that of HA [21].

Several methods have been developed for processing of HA coatings, which include thermal spraying [22], pulsed laser deposition (PLD) [23], sputtering [24], biomimetic [25], electrophoretic deposition [26] and sol-gel [27]. Among the possible alternatives, the sol-gel method has been chosen for the homogeneous composition and uniform and fine microstructure of the resultant coating, as well as for the simplicity and low cost of this procedure $[28,29]$.

In our present study we used ammonium fluoride $\left(\mathrm{NH}_{4} \mathrm{~F}\right)$ as the fluorine reagent for the preparation of FHA. However in several other studies, hexafluorophosphoric acid $\left(\mathrm{HPF}_{6}\right)$ has been used as the fluorine reagent [30-32]. Although $\mathrm{HPF}_{6}$ is a more effective reagent in comparison with $\mathrm{NH}_{4} \mathrm{~F}$ [33], increasing the time of refluxing, after addition of $\mathrm{NH}_{4} \mathrm{~F}$, it is possible to use $\mathrm{NH}_{4} \mathrm{~F}$ as a good fluorine reagent. Moreover, $\mathrm{NH}_{4} \mathrm{~F}$ has several other advantages in comparison with $\mathrm{HPF}_{6}$, which include simplicity and safety at work, easy availability and low cost.

\section{MATERIALS AND METHODS}

\section{Sol-gel synthesis and coating procedure Preparation of FHA solution}

Calcium nitrate tetrahydrate $\left(\mathrm{Ca}\left(\mathrm{NO}_{3}\right)_{2} \cdot 4 \mathrm{H}_{2} \mathrm{O}\right.$, Merck, $\mathrm{GR})$, phosphorous pentoxide $\left(\mathrm{P}_{2} \mathrm{O}_{5}\right.$, Merck, $\left.\mathrm{GR}\right)$ and ammonium fluoride $\left(\mathrm{NH}_{4} \mathrm{~F}\right.$, Aldrich, USA) were selected as Ca-precursor, P-precursor and fluorine reagent, respectively. In preparing the solutions, calcium nitrate tetrahydrate was dissolved in absolute ethanol giving rise to a $2 \mathrm{M} \mathrm{Ca}$ containing solution; phosphorous pentoxide was dissolved in absolute ethanol to form a $2 \mathrm{M} \mathrm{P}_{2} \mathrm{O}_{5}$ ethanol solution followed by a refluxing process for $24 \mathrm{~h}$ to obtain a clear Pcontaining solution. A stoichiometry amount of fluorine reagent $(x=1 ; P / F=6)$ was mixed with $P$ containing ethanol solution to form the $\mathrm{P}-\mathrm{F}$ mixture.
Ca-containing ethanol solution was added drop-wise into the P-F mixture to obtain a $\mathrm{Ca} / \mathrm{P}$ ratio of 1.67 . This mixed solution was refluxed for $32 \mathrm{~h}$ to obtain the FHA solution.

\section{Synthesis of FHA powders}

The FHA solution was kept in an oven at $120{ }^{\circ} \mathrm{C}$ for $12 \mathrm{~h}$, and the powder formed was introduced into four cuvettes, individually heated at a rate of 2 ${ }^{\circ} \mathrm{C} / \mathrm{min}$ up to $500,600,700$ and $800{ }^{\circ} \mathrm{C}$, respectively, and kept at these temperatures for $15 \mathrm{~min}$.

\section{Preparation of FHA Coating}

Plates of commercially pure titanium (c.p. Ti, grade 2 ), were polished with silicon carbide sandpapers (grit range of 200-1200), and ultrasonically cleaned in acetone for $15 \mathrm{~min}$, in $70 \%$ ethanol for $20 \mathrm{~min}$, and then in double-distilled water for $20 \mathrm{~min}$. They were used as substrates. The FHA layer was coated by a spin-coater (Spin Coater, Chemat, KW-4A, England) at a speed of $1500 \mathrm{rpm}$ for $15 \mathrm{~s}$ (spread cycle) and $3500 \mathrm{rpm}$ for $30 \mathrm{~s}$ (spin cycle), followed by heat treatment at $150{ }^{\circ} \mathrm{C}$ for $20 \mathrm{~min}$.

Then the substrates were heated in air at a rate of 2 ${ }^{\circ} \mathrm{C} / \mathrm{min}$ up to $500,600,700$ and $800{ }^{\circ} \mathrm{C}$ and were stored for $15 \mathrm{~min}$ at these temperatures. This spin coating-drying-firing process was repeated five times to obtain the desired coating thickness. The flowchart of the sol-gel process and coating is illustrated in Figure 1.

Powders and coating produced were characterized by X-ray diffraction (XRD, Philips, X'pert Pro, $\mathrm{Cu} \mathrm{K \alpha}$, Netherland), recorded at a scan speed of $1 \% \mathrm{~min}$. The chemical structure of the FHA was observed with Fourier transform infrared spectroscopy (FTIR, Nicolet Model 800, USA).

The powders were analyzed using differential thermal analysis (DTA, NETZSCH, Germany). Morphological observation of powders was performed in a transition electron microscope (TEM, Leo 912 AB, Germany). Surface morphology and section interface of FHA coating were characterized by scanning electron microscope (SEM, S 360, Oxford-England). 


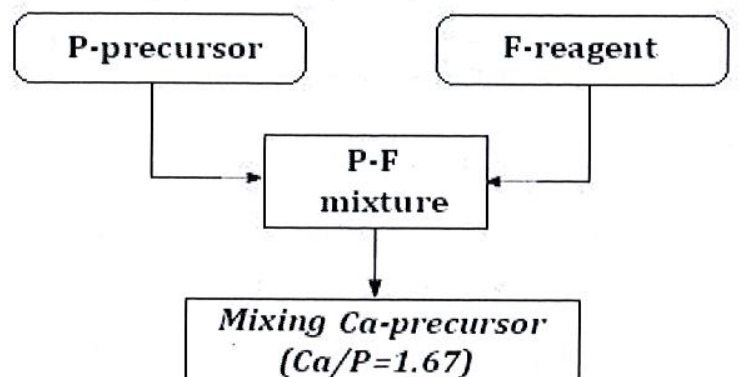

\section{RESULTS AND DISCUSSIONS}

\section{X-ray diffraction (XRD)}

The XRD patterns of the calcined FHA powders and coatings at 500,600,700 and $800{ }^{\circ} \mathrm{C}$ are shown in Figure 2 and Figure 3. All powders have similar diffraction profiles. The (002), (211), (112) and (300) peaks are those of the FHA structure [34]. Figure 3 shows the plots of the XRD profiles of the FHA coatings, after five spin coating-drying-firing processes, at $500,600,700$ and $800^{\circ} \mathrm{C}$ for $15 \mathrm{~min}$ in air.

The phases observed are the substrate, the apatite and the rutile. For all coatings, the main crystalline phase of coatings was calcium phosphate with apatite phase, and no obvious tricalcium phosphate $(\alpha$-TCP and $\beta$ -
TCP), calcium oxide $(\mathrm{CaO})$, calcium fluoride $\left(\mathrm{CaF}_{2}\right)$ or other phases as impurities were found in the XRD patterns. Increasing the temperature did not result in any change in the intensity of apatite peaks after 600 ${ }^{\circ} \mathrm{C}$ and no impurity was detected at this temperature, indicating high purity powders and coatings.

\section{Fourier transform infrared spectroscopy (FTIR)}

Figure 4 shows the FTIR spectroscopy of the sol-gel derived FHA after heat treatment at $600{ }^{\circ} \mathrm{C}$ for 15 min in air. The FHA powders showed phosphate bands at $570\left(v_{4}\right), 600\left(v_{4}\right), 960\left(v_{4}\right)$, and 1030-1090 $\left(v_{3}\right) \mathrm{cm}^{-1}$, hydroxyl $(\mathrm{OH})$ bands at 630 and $3570 \mathrm{~cm}^{-1}$, and $\mathrm{OH}-\mathrm{F}$ band (stretching) at $3540 \mathrm{~cm}^{-1}[35,36]$. Additionally, carbonate bands were observed at 870 and $1360 \mathrm{~cm}^{-1}$, indicating substitution of carbonate groups within the apatite structure [35]. 


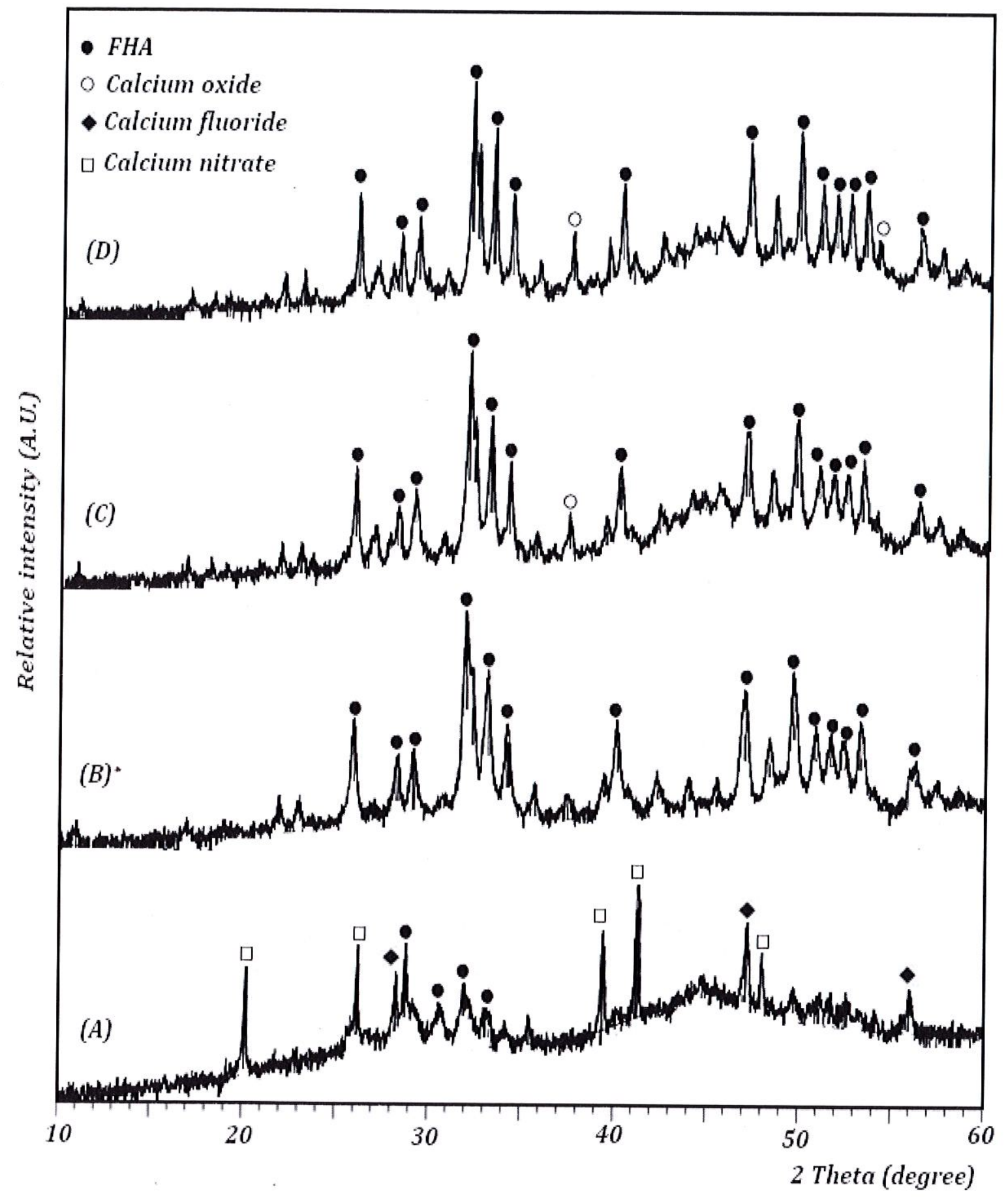

Figure 2. XRD of the sol-gel-derived FHA powders after heat treatment for $15 \mathrm{~min}$ at $500{ }^{\circ} \mathrm{C}(\mathrm{A}), 600{ }^{\circ} \mathrm{C}(\mathrm{B}), 700$ ${ }^{\circ} \mathrm{C}(\mathrm{C})$ and $800{ }^{\circ} \mathrm{C}(\mathrm{D})$ in air. 


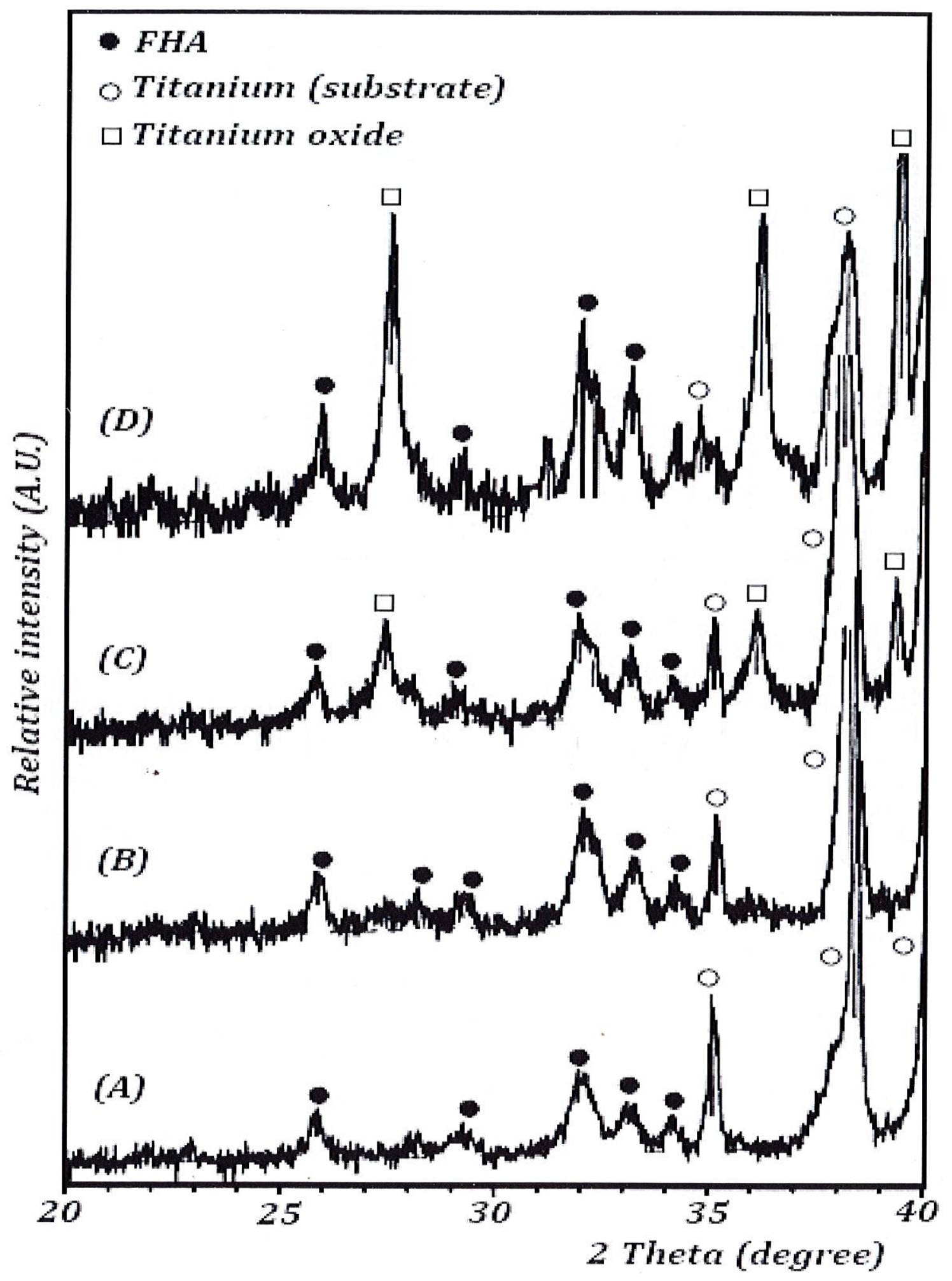

Figure 3. XRD of the sol-gel-derived FHA films on $\mathrm{Ti}$ substrates after spin coating and heat treatment for $15 \mathrm{~min}$ at $500{ }^{\circ} \mathrm{C}(\mathrm{A}), 600{ }^{\circ} \mathrm{C}(\mathrm{B}), 700{ }^{\circ} \mathrm{C}(\mathrm{C})$ and $800^{\circ} \mathrm{C}(\mathrm{D})$ in air. 


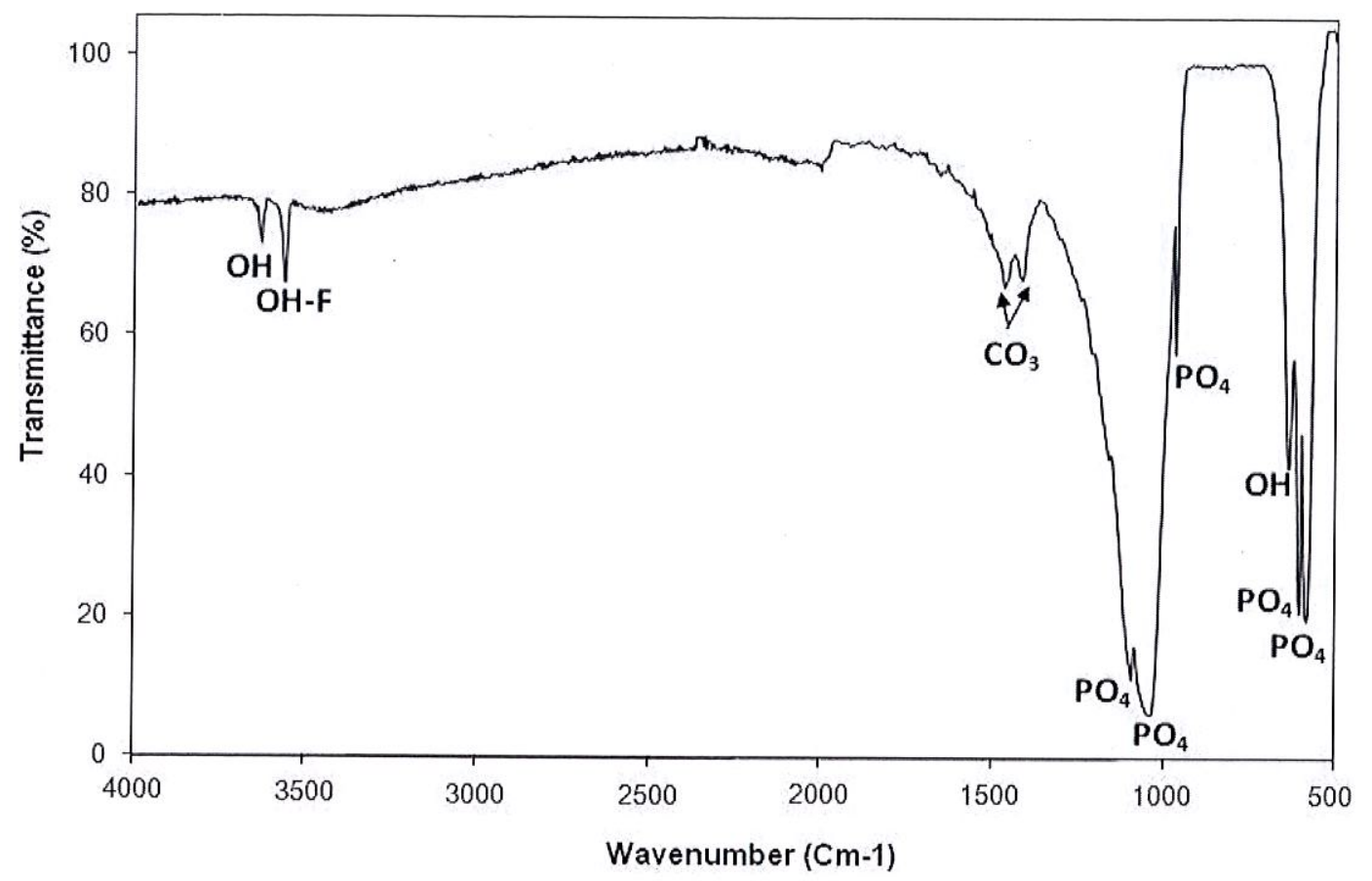

Figure 4. FTIR spectroscopy of the sol-gel derived FHA after heat treatment at $600{ }^{\circ} \mathrm{C}$ for 15 min in air.

\section{Particle size measurement}

The crystal size of the sintered FHA is inversely proportional to the peak width according to the Debye-Scherrer equation [37], where $\Delta(2 \theta)$ represents the peak width at half-maximum intensity of the reflection, $\lambda$ is the wavelength for $\mathrm{CuK}_{\alpha}(\lambda=$ $0.15418 \mathrm{~nm}$ ), and $\mathrm{D}$ is the crystal size in nanometers.

$\Delta(2 \theta)=\frac{0.9 \lambda}{D \operatorname{Cos}(\theta)}$

The crystallite sizes were estimated to range from 21.6 to $39.2 \mathrm{~nm}$ for the FHA powders calcined at 500 to $800{ }^{\circ} \mathrm{C}$, respectively. Table 1 shows the calculated particle size (D) of the FHA powders as a function of calcination temperatures.
Table 1. Calculated crystallite sizes of the FHA powders by the Debye-Scherrer's equation

\begin{tabular}{ccc}
\hline Sample & $\begin{array}{c}\text { Calcination } \\
\text { temperature }\left({ }^{\circ} \mathrm{C}\right)\end{array}$ & $\begin{array}{c}\text { Particle size } \\
(\mathrm{nm})\end{array}$ \\
\hline FHA1 & 500 & 21.6 \\
FHA2 & 600 & 26.5 \\
FHA3 & 700 & 31.6 \\
FHA4 & 800 & 39.2 \\
\hline
\end{tabular}

\section{Differential thermal analysis (DTA)}

Figure 5 shows the DTA curve of the dried FHA powders. A strong endothermic peak at about 100$150{ }^{\circ} \mathrm{C}$ indicates evaporation of residual volatiles such as water or ethanol, followed by a small exothermic peak at about $430-450{ }^{\circ} \mathrm{C}$ for FHA phase crystallization, and an endothermic peak at about $550-570{ }^{\circ} \mathrm{C}$ as a result of FHA phase transformation. There is no appreciable change in DTA curve at high temperatures $\left(600-800^{\circ} \mathrm{C}\right)$, indicating formation of stable FHA phase. 


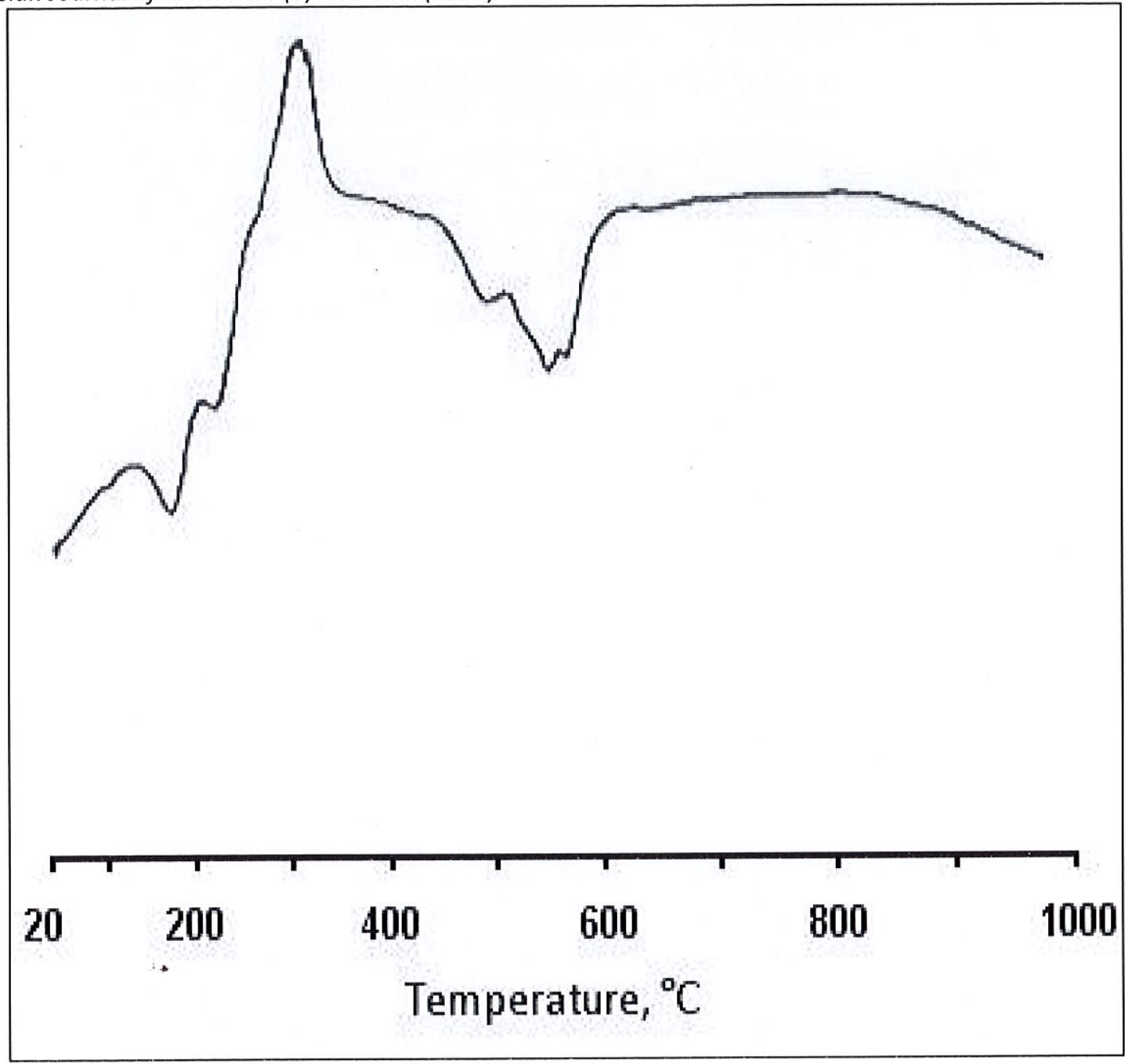

Figure 5. Differential thermal analysis (DTA) of the dried FHA powders.

\section{Scanning electron microscopy (SEM)}

Figure 6 shows the SEM morphologies of the FHA coatings on $\mathrm{Ti}$ substrate after the heat treatment at $600^{\circ} \mathrm{C}$ for $15 \mathrm{~min}$ in air. The surface morphology was dense and uniform (Figure 6(A)). The cross-section of FHA coatings was also dense and uniform with a thickness in the range of $1 \sim 1.5 \mu \mathrm{m}$ (Figure $6(\mathrm{~B})$ ), which was formed by a five spin coating steps. Moreover, there was no delamination or mismatch at the interface. $\mathrm{Ca} / \mathrm{P}$ molar ratios of FHA samples (powders and coating) were in the range of 1.57-1.64, which are similar to the stoichiometric value (1.67).

\section{Transmission electron microscopy (TEM)}

The nanocrystalline structure of the FHA powders was confirmed by TEM. Figure 7 shows representative TEM images recorded on copper grid with holly carbon film at different magnifications from the FHA powders. This result is in good agreement with the particle size measurement obtained using XRD patterns by Scherrer equation, which revealed that the particles were in the nanometer size range. 
Malaysian Journal of Science 29 (3): 252-261 (2010)

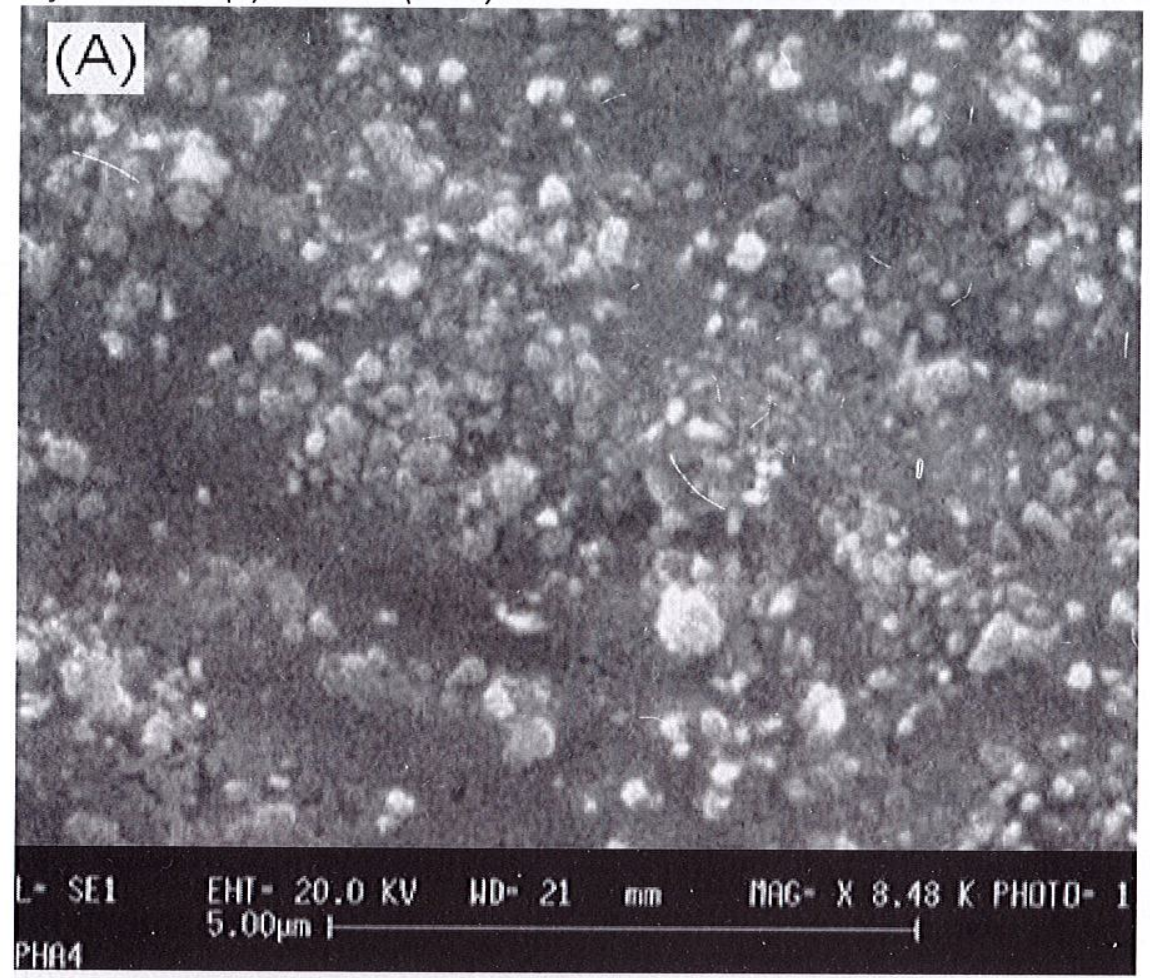

\section{(B)}

FHA

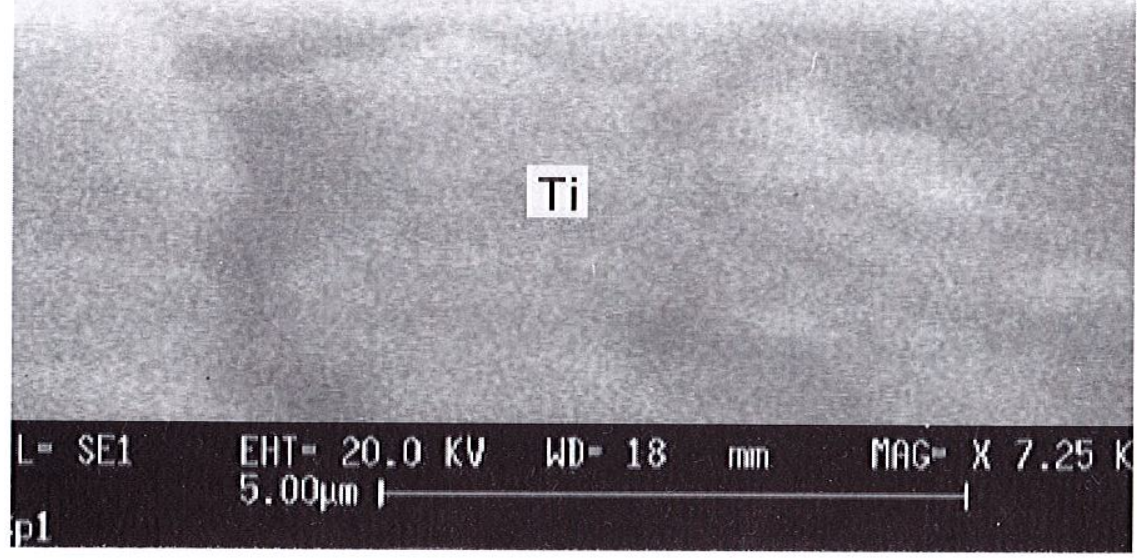


Figure 6. SEM morphology of the sintered FHA coatings on Ti substrate at $600^{\circ} \mathrm{C}$ for 15 min in air: surface morphology (A) and cross-section (B).
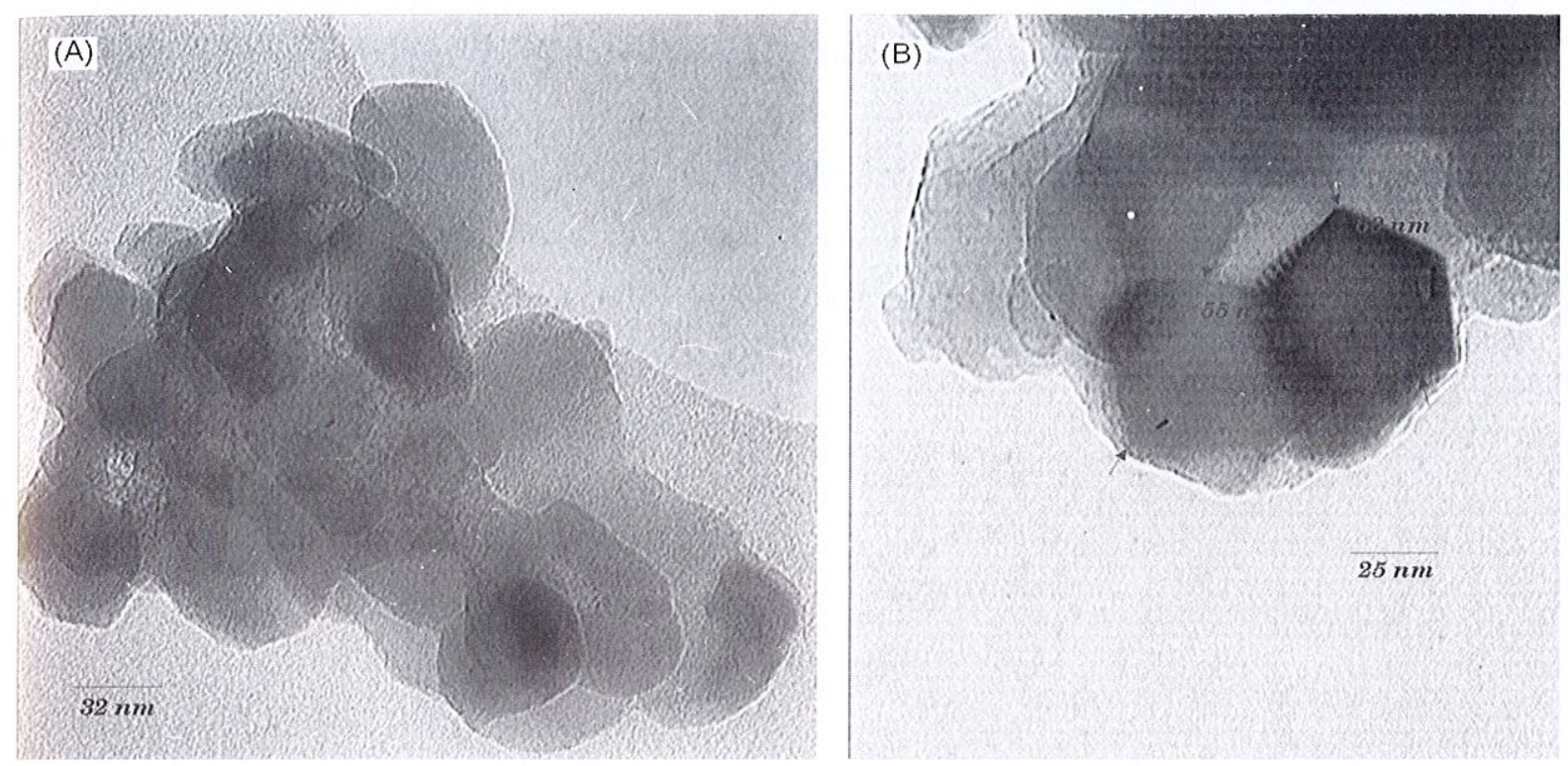

Figure 7. TEM images of the calcined FHA powders at $600^{\circ} \mathrm{C}$ for $15 \mathrm{~min}$ in air at different magnifications $(63000 \times$ (A), $80000 \times(B))$.

\section{CONCLUSIONS}

Fluorohydroxyapatite (FHA) has been successfully synthesized with $\mathrm{NH}_{4} \mathrm{~F}$ as the fluorine containing reagent by sol-gel spin coating method. XRD studies found that the apatite phase existed in powders and coatings with no impurity at $600^{\circ} \mathrm{C}$. The size of FHA particles, estimated by Debye-Scherrer equation and TEM results, ranges from 21.6 to $39.2 \mathrm{~nm}$. SEM results showed that the thin films were dense, uniform and had a thickness of about $1 \sim 1.5 \mu \mathrm{m}$.

\section{REFERENCES}

1. 1.Vallet-Regi M. (1997). J. An. Quim. Int. Ed. 93:6.

2. Black J. and Hastings G. (Eds.). (1998). Handbook of Biomaterial Properties, Chapman \& Hall, London.

3. Aoki H. (1994), Medical Applications of Hydroxyapatite, Ishiyaku EuroAmerica, Tokyo.

4. Nelea V., Morosanu C., Iliescuc M. and Mihailescu I. N. (2004). Appl. Surf. Sci. 228:346.

5. Yua L.-G., Khora K. A., Lia H. and Cheang P. (2003). Biomaterials 24: 2695.

6. Khor K. A. and Cheang P. (1997). J. Mater. Process. Technol. 63:271.
7. Yang Y. C. and Cheang E. (2001). Biomaterials 22:1827.

8. Bao Q., Chen C., Wang D., Li T. and Liu J. (2006). Mater. Sci. Eng. A 429:25.

9. Lu Y.-P., Xiao G.-Y., Li S.-T., Sun R.-X. and Li M.-S. (2006). Appl. Surf. Sci. 252:2412.

10. Breme J. (1989). Mem. Etudes. Sci. Rer-Metall. $86: 625$.

11. Lio D. -M., Yang Q. and Troczynski T. (2002). Biomaterials 23(3):691.

12. Adell R., Lekholm U. and Rockler B. (1981). Int. J. Oral. Surg. 10:387.

13. Ranter B. (1993). J. Biomed. Mater. Res. 27:837.

14. Chiche G. J. and Block M. S. (1989). A. Pinault, International Journal of Oral \& Maxillofacial Implants, 4:219.

15. Nanci A., Wuest J. D., Peru L., Brunet P., Sharma V., Zalzal S. and Mckee M.D. (1998). J. Biomed. Mater. Res. 40:324.

16. Hench L.L. (1991). J. Am. Ceram. Soc. 74 (7): 1485 .

17. McPherson E., Lawrence D., Thomas A. and Saberi M. (1995). Clin. Orthop. 315:223.

18. Albrektsson T., Branemark P. L., Hansson H. A. and Lindstrom J. (1981). Acta Ortho Scand. $52: 155$. 
Malaysian Journal of Science 29 (3): 252-261 (2010)

19. Gineste L., Gineste M., Ranz X., Ellefterion A., Guilhem A., Rouquet N. and Frayssinet P. (1999).

J. Biomed. Mater. Res. 48:224.

20. Overgaard S., Lind M., Josephsen K., Maunsbach A.B., Bünger C. and Søballe K. (1998). J. Biomed. Mater. Res. 39:141.

21. Barinov S.M., Tumanov S.V., Fadeeva I.V. and Bibikov V.Y. (2003). Inorg. Mater. 39:877.

22. Bhadang K.A., Karlis K.A. and Gross A. (2004). Biomaterials 25:4935.

23. Nelea V., Ristoscu C., Chiritescu C., Ghica C., Mihailescu I.N., Pelletier H., Mille P. and Cornet A. (2000). Appl. Surf. Sci. 168:127.

24. Ding S., Ju C. and Lin J. (1999). J. Biomed. Mater. Res. 44:266.

25. Habibovic P., Barrere F., van Blitterswijk C.A., de Groot K. and Layrolle P. (2002). J. Am. Ceram. Soc. 85:517.

26. De Sena L.Á., de Andrade M.C., Rossi A.M. and Soares G. de A. (2002) J. Biomed.

Mater. Res. 60:1.

27. Mavis B. and Cuneyt Tas A. (2000). J. Am. Ceram. Soc. 83:989.

28. Weng W. and Baptista J.L. (1998). J. Mater. Sci. Mater. Med. 9:159.

29. Liu D.M., Yang Q., Troczynski T. and Tseng W.J. (2002). Biomaterials 23:1679.

30. Cheng K., Han G.R., Weng W.J., Qu H.B., Du P.Y., Shen G., Yang J. and Feireira J.M.F. (2003). Mater. Res. Bull. 38:89.

31. Zhang S., Xjanting Z., Yongsheng W., Kui C. and Wenjian W. (2006). Surf. Coat. Technol. 200:6350.

32. Cheng K., Zhang S. and Weng W. (2006). Thin Solid Films 515:135.

33. Cheng K., Zhang S. and Weng W. (2006). Journal of Sol-Gel Science and Technology 38:13.

34. Lerner E., Sarig S., Azoury R. (1991). J. Mater. Sci. Mater. Med. 2:138.

35. Elliott J.C. (1994). Structure and chemistry of the apatites and other calcium orthophosphates, London, Elsevier.

36. Sudarsanan K., Mackie P.E. and Young R.A. (1972). Mater. Res. Bull., 7:1331.

37. Azaroff L.A. (1968). Elements of X-ray crystallography, New York, McGraw-Hill, p.552. 